\title{
Permanent Confiscation of Prison Contraband: The Fifth Amendment Behind Bars
}

Courts have generally failed to recognize that a prisoner has a property interest in prison contraband. ${ }^{1}$ Prison officials thus may permanently confiscate prison contraband in addition to subjecting the offending prisoner to traditional means of discipline, such as loss of privileges or good-time credits. Confiscation may occur regardless of the item's value, whether its possession is legal outside of the prison context, or whether the legislature has authorized confiscation.

This Note argues that although prisoners do not retain possessory rights in prison contraband, they do retain ownership rights, and. thus a property interest, in items that were legally possessed before being smuggled into prison. Most courts to date have neglected to address this issue squarely and have instead simply dismissed these cases without considering the merits. The few courts that have examined whether a property interest exists have erred in their analyses. This Note argues that a property interest does exist in many forms of prison contraband, and thus that the contraband may not be permanently confiscated absent clear statutory authority. Furthermore, whenever a confiscation is made, be it temporary or permanent, ${ }^{2}$ prison officials must provide some procedural protections. The Note delineates the factors courts should consider in reviewing the adequacy of such protections. ${ }^{3}$

1. This Note defines prison contraband as items that have been smuggled into prison contrary to prison regulations. It includes both items illegal to possess in any context (e.g., marijuana) and those illegal to possess only in prison (e.g., currency, jewelry, hard-cover books).

2. In a temporary confiscation, prison officials eventually either return the property to the prisoner upon his release or send it to a non-prisoner designated by the prisoner. In a permanent confiscation, the state never returns the property.

3. The Note is concerned only with property confiscated pursuant to a prison regulation. For a case treating loss of a prisoner's property through prison officials' negligence or recklessness, see Parratt v. Taylor, 451 U.S. 527 (1981) (hobby materials received in mail lost through prison officials' negligence). For cases discussing legitimately held property allegedly taken out of malice or thievery, 


\section{The Courts' Failure To Reach Due Process Questions in Prison Contraband Gases}

Historically, courts have simply dismissed prisoners' claims regarding property confiscations. The courts operated under two now-discredited assumptions: (i) that property claims could not be brought under section $1983 ;$ and (ii) that courts should accord extreme deference to prison officials. $^{5}$

In 1972, the Supreme Court firmly rejected the first rationale for dismissing confiscation cases in Lynch $v$. Household Finance Corp. ${ }^{6}$ which explicitly stated that property claims could be brought under section 1983.7

The doctrine of extreme judicial deference toward prison administrators, known as the "hands-off" doctrine, ${ }^{8}$ has also been eroded in recent

see Ferranti v. Moran, 618 F.2d 888 (1st Gir. 1980) (guard allegedly took prisoner's radio and destroyed it for no legitimate reason); Russell v. Bodner, 489 F.2d 280 (3d Gir. 1973) (guard took seven packages of prisoner's legitimately held cigarettes to "prove" prisoner had no remedy). See generally Note, Prisoner Property Deprivations: Section 1983 and the Fourteenth Amendinent, 52 IND. L.J. 257 (1976) (focusing on when deprivations due to prison officials' negligence, thievery, or malice should be actionable under § 1983).

4. 42 U.S.C. $\S 1983$ (1976), together with its jurisdictional counterpart, 28 U.S.C. $\S 1343(3)$ (1976), provides a cause of action for "the deprivation of any rights, privileges, or immunities secured by the Constitution and laws" by any person acting "under color of any statute, ordinance, regulation, custom, or usage, of any State or Territory . . . ." Examples of prison cases ruling that $\$ 1983$ did not apply to property claims include Rhodes v. Sigler, 448 F.2d 1237 (8th Cir. 1971) (dispute over \$2.46); Howard v. Higgins, 379 F.2d 227 (10th Cir. 1967) (personal property valued at $\$ 500$ not returned on inmate's release).

5. See, e.g., Howard v. Swenson, 426 F.2d 277, 277 (8th Cir.) (shoes taken; courts should "interfere" only in "extreme" cases), cert. denied, 400 U.S. 948 (1970); United States ex rel. Wagner v. Ragen, 213 F.2d 294, 295 (7th Gir.) (prisoner's oil paintings confiscated; courts' function not to superintend treatment and discipline of prisoners, but only to deliver from imprisonment those illegally confined), cert. denied, 348 U.S. 846 (1954).

6. 405 U.S. 538 (1972).

7. "This Court has never adopted the distinction between personal liberties and proprietary rights as a guide to the contours of $\S 1343(3)$ jurisdiction. Today we expressly reject that distinction." Id. at 542. "That rights in property are basic civil rights has long been recognized." Id. at 552. Although Lynch was not a prison property case, such cases have followed its holding and heard claims brought under § 1983. See, e.g., Jenson v. Klecker, 648 F.2d 1179, 1183 (8th Cir. 1981); Kimbrough v. O'Neil, 545 F.2d 1059 (7th Cir. 1976). Courts have allowed $\S 1983$ actions even when the property at stake is of little value. See, e.g., Weddle v. Director Patuxent Inst., 405 U.S. 1036 (1972) (\$3.52 worth of personal property); Russell v. Bodner, 489 F.2d 280 (3d Cir. 1973) (seven packages of cigarettes). Commentators are divided as to whether courts should do so. Compare McCormack, The Expansion of Federal Question Jurisdiction and the Prisoner Complaint Caseload, 1975 Wis. L. REv. 523, 549-50 (courts should allow such actions) with Note, supra note 3, at 260-62 (courts should generally rely on state remedies).

In Parratt v. Taylor, 451 U.S. 527 (1981), the Supreme Court dismissed a § 1983 action involving property lost through prison officials' negligence, reasoning that because a state remedy remained open to the prisoner there was no violation of the due process clause. Id. at 543. The Court was careful to note, however, that its holding extended only to where "the deprivation did not occur as a result of some established state procedure." Id. Thus, Parratt's holding would not extend to cases involving confiscation pursuant to an established state procedure. See also Fiallo v. de Batista, 666 F.2d 729, 733 (1st Cir. 1981) (noting in dictum that Parratt does not extend to cases involving property lost pursuant to an established state procedure).

8. See generally J. Gobert \& N. Cohen, Rights of Prisoners 7-8 (1981) (hands-off doctrine 
years, as the Supreme Court has recognized that "convicted prisoners do not forfeit all constitutional protections by reason of their conviction and confinement in prison." Where the retention of a constitutional right is consistent with a person's incarceration, that right is retained. ${ }^{10}$ Included among those rights that might be retained are property rights. ${ }^{11}$

The increasing recognition of prisoners' constitutional rights made courts less hesitant to intervene in the internal affairs of prisons to protect those rights. ${ }^{12}$ The countervailing administrative reasons supporting the hands-off doctrine came to be seen as insufficient justification for such complete deference, and the Supreme Court put the doctrine to rest in $1974 .{ }^{13}$

stemmed from judicial concerns about separation of powers, federalism, and lack of judicial expertise in internal operations of prisons); Comment, Bejond the Ken of the Courts: A Critique of Judicial Refusal to Review the Complaints of Convicls, 72 YALE L.J. 506 (1963) (analyzing "hands-off" doctrine).

9. Bell v. Wolfish, 441 U.S. 520, 545 (1979) (dictum); see Vitek v. Jones, 445 U.S. 480 (1980) (involuntary transfer of prisoner to mental hospital implicated protected liberty interest); Jones v. North Carolina Prisoners' Labor Union, 433 U.S. 119, 129 (1977) (dictum that prisoners are entitled to rights under First Amendment); Wolff v. McDonnell, 418 U.S. 539, 555 (1974) (protected liberty interest recognized in prisoner's good-time credits; "a prisoner is not wholly stripped of constitutional protections when he is imprisoned for crime"); Procunier v. Martinez, 416 U.S. 396, 419-22 (1974) (ban on attorney-client interviews conducted by paralegals or law students employed by attorneys violated prisoners' right of access to courts under Fourteenth Amendment). See generally J. GoBERT \& N. CoHEN, supra note 8, at 8-9 (noting rejection of hands-off doctrine and expansion of recognized rights in past twenty years).

10. See Coffin v. Reichard, 143 F.2d 443, 445 (6th Cir. 1944) ("A prisoner retains all the rights of an ordinary citizen except those expressly, or by necessary implication, taken from him by law."); see also Procunier v. Martinez, 416 U.S. 396, 422-23 (1974) (Marshall, J., concurring) (quoting Coffin for same point); Sostre v. McGinnis, 442 F.2d 178, 189 (2d Cir. 1971) (same). Additional support for this can be found in Proposed Standard 1.1 of the American Bar Association's Joint Committee on the Legal Status of Prisoners, as amended Feb. 9, 1981, which provides that "prisoners retain all rights of free citizens except where restrictions are necessary to assure orderly confinement and interaction, to provide reasonable protection for the rights and physical safety of the public and all members of the prison system, or as otherwise provided by the [ABA] Standards." J. GOBERT \& N. CoHEN, supra note 8, at 1-2 (Supp. June 1983) (discussing Proposed Standard).

11. See Parratt v. Taylor, 451 U.S. 527, 529 n.1, 540 (1981) (prisoner enjoys a protected property interest in hobby materials sent to him by mail but lost through negligence of prison officials); Wolff v. McDonnell, 418 U.S. 539, 556 (1974) ("Prisoners may . . . not be deprived of life, liberty, or property without due process of law.").

12. See, e.g., Soloway v. Weger, 389 F. Supp. 409, 410-11 (M.D. Pa. 1974) (prisoner's right to apply for parole was protected liberty interest); National Prisoners Reform Ass'n v. Sharkey, 347 F. Supp. 1234, 1237 (D.R.I. 1972) (temporarily enjoining prison officials from interfering with prisoner association's meetings protected by First Amendment). See generally SouTH Carouina DEP'T of Corrections, The EMERging Rights of THE Confined at i (1972) ("The judicial system is beginning to recognize many basic rights of [prisoners] . . . rights which virtually everyone took for granted as having been forfeited by one who was incarcerated . . ..").

13. Procunier v. Martinez, 416 U.S. 396, 405-06 (1974) ("[A] policy of judicial restraint cannot encompass any failure to take cognizance of valid constitutional claims whether arising in a federal or state institution. When a prison regulation or practice offends a fundamental constitutional guarantee, federal courts will discharge their duty to protect constitutional rights."). The doctrine could hold up only as Iong as prisoners had few protected rights; before the decline of the doctrine, judges did not need to reach the question of what rights survived incarceration. J. GOBERT \& N. CoHEN, supra note 8, at 8 . The combined forces of an increasingly militant and assertive prison population, an emerging civil rights/civil liberties bar and the Warren Court's responsiveness to the plight of society's under- 
Perhaps because these developments are relatively recent, however, courts have still not developed a coherent method of analysis to apply in prison contraband cases. Indeed, the deference shown by some courts in prison contraband cases is so extreme as to be the equivalent of the handsoff doctrine. ${ }^{14}$ In most cases, courts extend their review only to determine whether the prisoner received adequate notice that the items in question were prohibited ${ }^{15}$ or whether adequate procedures were used to determine whether the confiscated items were indeed contraband. ${ }^{16}$ Courts have not even attempted to address whether a property interest exists in prison contraband or, if so, what due process requires before such an interest is terminated. In light of the recent willingness of most courts to intervene when constitutional interests are implicated, the continued failure in prison contraband cases to reach these questions suggests an implicit ruling that no property interest exists in prison contraband, or that, even if a property interest does exist, there is sufficient authority for its forfeiture. The following sections argue that both of these rulings are in error.

\section{The Property Interest in Prison Contraband}

To determine whether a person's right to due process under the Fifth and Fourteenth Amendments has been violated in a property case requires a two-part test. First, the court must determine whether a property interest exists. ${ }^{17}$ Second, if such an interest does exist, the court must decide whether the requirements of due process were observed before the person was deprived of the protected interest. ${ }^{18}$ Thus, before a prisoner may raise a constitutional claim concerning the denial or destruction of property, he must show that he holds some interest in that property. To establish a

privileged set in motion the judiciary's eventual rejection of the excessive deference of the hands-off doctrine. Id. at 1-9. See generally Haas, Judicial Politics and Correctional Reforn: An Analysis of the Decline of the "Hands-off' Doctrine, 1977 DET. C.L. REv. 795 (arguing that basis for hands-off doctrine no longer exists and that judiciary has thus become effective forum for redressing prisoners' grievances).

14. See, e.g., Sullivan v. Ford, 609 F.2d 197, 198 (5th Cir.) (upholding confiscation of $\$ 2,197.40$ and stating that "[j]udicial interference with prison administration should be avoided whenever possible"), cert. denied, 446 U.S. 969 (1980); Butler v. Bensinger, 377 F. Supp. 870, 875 (N.D. Ill. 1974) (confiscation of prisoner's property falls within rubric that federal court will "interfere" with matters involving the internal management of state prison only in "exceptional" circumstances); Cardwell v. Hogan, 23 Ariz. App. 475, 476, 534 P.2d 283, 284 (1975) (confiscation of $\$ 340$ upheld on grounds that "[w]ide discretion is vested in correctional authorities").

15. See Pepperling v. Crist, 678 F.2d 787, 789 (9th Cir. 1982) (upholding confiscation in absence of statutory authority, reasoning that "in most cases complained of, prisoners were in possession of contraband, items they knew were subject to confiscation").

16. See Sherman v. MacDougall, 656 F.2d 527, 528 (9th Cir. 1981); Wolfish v. Levi, 573 F.2d 118, 131-32 \& n.29 (2d Cir. 1978), rev'd on other grounds sub nom. Bell v. Wolfish, 441 U.S. 520 (1979).

17. Board of Regents v. Roth, 408 U.S. 564, 570-71 (1972).

18. Goldberg v. Kelly, 397 U.S. 254, 261-62 (1970). 
property interest, one looks not to the Constitution but to "existing rules or understandings that stem from an independent source such as state law ...." 19

Courts have failed to find a property interest in any prison contraband because they have failed to look to the proper "independent source of law." Courts have confused prison contraband with conventional contraband and looked for a property interest in prison contraband as such. Courts should instead begin their analyses earlier, looking not to an interest in the item as prison contraband, but to the interest held in the item before it became contraband by being brought into prison (e.g., the interest held in money earned in the course of one's employment and legally possessed outside of prison).

\section{A. "Internal" and "External" Prison Contraband}

Prison contraband may consist either of items illegal to possess only if the possessor is a prisoner, "internal" prison contraband, or of items illegal for anyone to possess, "external" prison contraband.

External prison contraband may be either "contraband per se" or "derivative contraband". Contraband per se, such as marijuana or a sawedoff shotgun, is illegal to possess regardless of the context in which it is held. Thus, no property interest can ever exist in it. ${ }^{20}$ In contrast, derivative contraband, such as an automobile used to transport illegal narcotics, is illegal only because it has been used as part of an illegal course of action. ${ }^{21}$ The initial property interest in derivative contraband is not lost until the item is used in violation of a statute calling for its forfeiture; ${ }^{22}$ without such a statute, the property interest is retained and the item is not forfeited even though it may have been used in violation of the law. ${ }^{23}$ Whether per se or derivative contraband, however, external contraband

19. Roth, 408 U.S. at 577; see also Parratt v. Taylor, 451 U.S. 527, 529 n.1 (1981) (quoting Roth and noting absence of contention that no property interest existed in prisoner's package negligently lost by prison officials).

20. See United States v. Jeffers, 342 U.S. 48, 53 (1951) ("[N]o property rights shall exist' in contraband goods . ...") (quoting 26 U.S.C. $\S 3116$ ) (now at 26 U.S.C. $\$ 7302$ (1976)); State v. McNichols, 63 Idaho 100, 104, 117 P.2d 468, 470 (1941) ("slot machines . . . are not property but contraband subject to seizure and summary destruction") (citations omitted).

21. See, e.g., One 1958 Plymouth Sedan v. Pennsylvania, 380 U.S. 693, 699 (1965) (involving automobile used to transport illegally manufactured alcohol and distinguishing case from Jeffers and others involving contraband per se because latter may be forfeited even pursuant to an illegal search); United States v. $\$ 2500$ in United States Currency, 689 F.2d 10 (2d Cir. 1982) (forfeiture of money gained through sale of heroin).

22. See, e.g., United States v. One Douglas A-26B Aircraft, 436 F. Supp. 1292, 1298 n.7 (S.D. $\mathrm{Ga} .1977$ ) (sovereign's title to aircraft used to transport marijuana vests immediately upon forbidden use); Farley v. \$168,400.97, 55 N.J. 31, 40, 259 A.2d 201, 206 (1969) (sovereign's title to money used in violation of gambling statutes vests immediately upon forbidden use). Even here, however, the plaintiff retains enough of a property interest to deserve procedural protections, see infra p. 915 .

23. See infra p. 912. 
can never be the subject of any kind of property interest even before its possessor enters prison.

While many items of prison contraband (e.g., marijuana) are external contraband and thus not the subject of a property interest even before a prisoner illegally brings them into prison, internal prison contraband (e.g., money, jewelry, prohibited literature) is legally possessed before it is brought into prison, and is thus the subject of a property interest. ${ }^{24}$ This pre-existing property interest in internal prison contraband is constitutionally protected. And just as forfeiture of a free person's interest in derivative contraband requires clear statutory authority, ${ }^{25}$ forfeiture of a prisoner's property interest in internal prison contraband should also require such authority. Before a more specific discussion of the implications of this assertion, however, the Note analyzes the inconsistencies of the current treatment of prison contraband.

24. This certainly holds true where the possessor was the legal owner of the interest outside of the prison (as, for instance, where the property came into his possession as consideration for labor or property traded in return, or by gift or bequest). But even where the plaintiff was not the legal owner outside of the prison, but was merely in possession of the goods (for example, if he found the property), he would still have a property interest in the goods, valid as against any claimant (including the state) except the true owner. See, e.g., Cesarini v. United States, 296 F. Supp. 3, 7 (N.D. Ohio 1969), aff'd, 428 F.2d 812 (6th Cir. 1970). See generally R. Boyer, Survey of Property 679-80 (3d ed. 1981) ("Possession is a basic property interest entitling the possessor to certain rights . . . ."). Even where the prisoner from whom the confiscation occurred did not have an interest in the item before it entered the prison, but instead came into possession when a visitor or another prisoner transferred it to him, he still would hold a property interest. See infra note 59.

Of course, this would not be true if the item were external contraband (e.g., narcotics or money gained through the illegal sale of narcotics) when there was a statute calling for its forfeiture. See United States v. $\$ 2500$ in United States Currency, 689 F.2d 10 (2d Cir. 1982). In such a case, the possessor would not have had a property interest even before bringing the item into prison.

The fact that possession of internal prison contraband was legal outside of the prison not only means that a property interest existed in such contraband, but also that returning it to the prisoner upon his release or sending it to persons he designates outside of prison would not result in criminal possession. In One 1958 Plymouth Sedan v. Pennsylvania, 380 U.S. 693 (1965), the Court drew this distinction regarding the return of confiscated contraband in the non-prison context. There state officials, as authorized by statute, confiscated illegally manufactured liquor and the vehicle used to transport the liquor. Remanding the case for a determination of whether the search was illegal, the Court noted that a finding of illegality would require the return of the automobile but not of the liquor, as the latter was contraband per se rather than merely derivative contraband, and its return would subject plaintiff to possible criminal penalties for possession. Id. at 699 .

25. While most courts have failed to discern this distinction between contraband per se and derivative contraband with regard to prison contraband, see, e.g., Lowery v. Cuyler, 521 F. Supp. 430 (E.D. Pa. 1981) (discussed infra p. 907), one court has explicitly noted the distinction, see Balckom v. Heptinstall, 152 Ga. App. 539, 263 S.E.2d 275 (1979), cert. dismissed, 245 Ga. 567, 267 S.E.2d 623 (1980) (disallowing permanent confiscation of $\$ 2000$ because money was not inherently unlawful, i.e., malum in se, but became unlawful only under certain specific circumstances, and no statutory authority existed for confiscation). Although the court did not explicitly state that the existence of a property interest turned on this distinction, such a finding is implicit in its holding. 


\section{B. Courts' Treatment of the Property Interest in Prison Contraband}

Most courts appear unaware of their failure even to discuss whether a previously protected interest was affected by the confiscation at issue. Without examining whether the property at issue is external or internal prison contraband, courts dismiss a case after establishing only that the items at issue are "contraband," 26 or require merely that prison officials provide procedural protections to determine whether the items might have been legitimately held. ${ }^{27}$ Such opinions violate the spirit, if not the letter, of the cases concerning the constitutional protection of property interests. ${ }^{28}$

Only two cases have directly addressed the question of whether a property interest exists in prison contraband. Sell v. Parratt ${ }^{29}$ explicitly held that a property interest exists ${ }^{30}$ and discussed the consequences of its ruling. Lowery $v$. Cuyler ${ }^{31}$ is the only case that explicitly sets forth its reasons for not finding a property interest in prison contraband.

Sell v. Parratt disallowed the permanent confiscation of about five hundred dollars held as prison contraband ${ }^{32}$ and explicitly recognized a property interest in it. Citing Board of Regents $v$. Roth, ${ }^{33}$ the court looked to state common law and found the source for a property interest in prison

26. See, e.g., Pepperling v. Crist, 678 F.2d 787, 789 (9th Cir. 1982) (prisoners' claims that property is often damaged or stolen during searches dismissed on basis that most claims concerned contraband); Sullivan v. Ford, 609 F.2d 197, 198 (5th Cir.) (upholding confiscation of over $\$ 2000$ on basis that it was contraband, and that regulation under which it was confiscated was "reasonable"), cert. denied, 446 U.S. 969 (1980).

27. See Sherman v. MacDougall, 656 F.2d 527, 528 (9th Cir. 1981) (court looked only to whether adequate procedural protections were provided for confiscation of prisoner's prohibited magazines); United States ex rel. Wolfish v. United States, 428 F. Supp. 333, 342 (S.D.N.Y. 1977) (requiring procedural protections to determine whether items taken were contraband and thus within regulations calling for their destruction, but not questioning officials' authority to destroy or otherwise permanently to confiscate items subject to the regulations), aff'd sub nom. Wolfish v. Levi, 573 F.2d 118 (2d Cir. 1978), rev'd on other grounds sub nom. Bell v. Wolfish, 441 U.S. 520 (1979).

28. See infra pp. $912-16$

29. Sell v. Wolff, No. GV74-L-63 (D. Neb. Feb. 4, 1976), aff'd sub nom. Sell v. Parratt, 548 F.2d 753 (8th Cir.), cert. denied, 434 U.S. 873 (1977). The unreported district court opinion will often be cited in this Note in describing the reasoning behind the Eighth Circuit's holding because the Eighth Circuit simply accepted the district court's conclusion that Nebraska's common law gave prisoners a possessory interest in prison contraband without giving any detailed discussion or analysis of its finding that a property interest exists.

30. See also Hanvey v. Blankenship, 474 F. Supp. 1349 (W.D. Va. 1979) (implicitly recognizing property interest in $\$ 750$ but also finding clear statutory authority to confiscate), aff'd, 631 F.2d 296 (4th Cir. 1980); Balckom v. Heptinstall, 152 Ga. App. 539, 263 S.E.2d 275 (1979), cert. dismissed, $245 \mathrm{Ga} .567,267$ S.E.2d 623 (1980) (implicitly recognizing prisoner's property interest in $\$ 2000$ ) (discussed supra note 25).

31. 521 F. Supp. 430 (E.D. Pa. 1981).

32. It is not clear from the Sell opinions, nor from most of the confiscation opinions discussed in this Note, how the inmate came to possess this property. Unless otherwise stated, the Note assumes that the contraband was legally possessed before it was smuggled into prison. Of course, if it were not legally possessed no property interest would exist in it as prison contraband, since none would have existed in it even before it was brought into prison. See supra note 24.

33. 408 U.S. 564 (1972) (discussed infra p. 912). 
contraband $^{34}$ in the doctrine that the mere possession of items gives rise to a property interest, valid "against all except the person who can prove a superior interest." mate's interest could not be taken away without clear statutory authority.$^{36}$ Unable to find such authority, the court held for the prisoner. ${ }^{37}$

Sell's analysis of the source and existence of a property interest in prison contraband, although correct in looking to state common law for the property interest and in concluding that a property interest exists, is in part flawed. Sell looked for a property interest in the items at issue as prison contraband. But the sources of state law which Sell cited were neither statutes nor prison cases. ${ }^{38}$ Sell's language implies that because non-prisoners have a common law property interest in any property they possess, prisoners likewise have a common law interest in any prison contraband they possess.

This assertion is both novel and, by itself, insufficient. Never before had the courts in the Eighth or any other circuit recognized any kind of interest held by the possessor of prison contraband, ${ }^{39}$ and it is doubtful that the non-prison common law cases were meant to extend to prison cases. This is particularly true in light of the fact that they were decided during periods when prisoners' constitutional rights received little judicial solicitude. ${ }^{40}$ Moreover, Sell failed to deal with the position, advanced in opinions both before and after Sell, that permanent confiscation is necessary to deter prisoners from bringing contraband into prison. ${ }^{41}$ Finally, the Eighth Circuit's decision did not provide the reasoning behind the finding of a property interest, but merely agreed with the district court's unre-

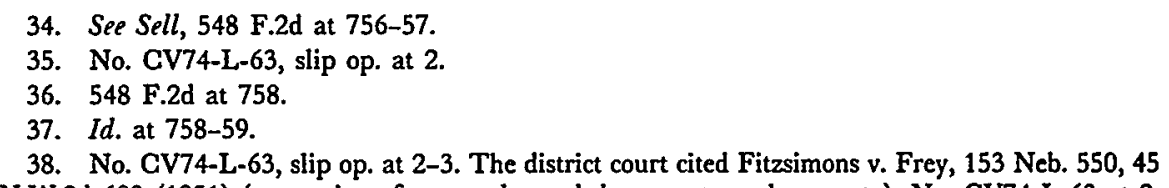
N.W.2d 603 (1951) (conversion of personalty and damages to real property), No. CV74-L-63 at 2, and Barkley v. Leiter, 49 Neb. 123, 68 N.W. 381 (1896) (sheriff's seizure of goods, apparently for repayment of tax), No. GV74-L-63 at 2. It also cited 36A C.J.S. Finding Lost Goods § 5, at 421 (1961) ("By the general rule of common law one who finds and appropriates a lost chattel ... acquires the title thereto and the right to possession thereof against all the world except the true owner."), reasoning that this rule probably obtains in Nebraska, No. CV74-L-63 at 3.

39. Whereas this Note argues that Sell is correct in saying prisoners hold a property interest in contraband they possess, this is not because, as Sell's holding implies, the common law had recognized an interest in prison contraband as such. The courts had never done so. See supra p. 899. The interest stems rather from the ownership interest held in the item before it is brought into prison, see infra pp. 909-11.

40. Barkley was written in 1896 and Fitzsimmons in 1951, see supra note 38, while prisoners' constitutional rights were largely ignored until about twenty years ago, see J. GOBERT \& N. CoHEN, supra note 8 , at 1 .

41. See Lowery v. Cuyler, 521 F. Supp. 430, 433 (E.D. Pa. 1981); Gardwell v. Hogan, 23 Ariz. App. 475, 476-77, 534 P.2d 283, 284-85 (1975). 
ported reasoning on this matter. ${ }^{42}$ These flaws have left the case in relative isolation: It has been followed in only one other circuit, ${ }^{43}$ and remains either explicitly or implicitly rejected ${ }^{44}$ in all others. ${ }^{45}$

Lowery $v$. Cuyler ${ }^{46}$ is the only other prison contraband case that has attempted to address the due process questions. Like Sell, Lowery involved the permanent confiscation of a large sum of money; like Sell, it cited Roth for the proposition that a court must determine whether state law recognizes a property interest in the confiscated goods. ${ }^{47}$ The Lowery court noted that Sell had found a property interest in Nebraska law, ${ }^{48}$ but did not analyze Sell's reasoning ${ }^{48}$ or determine whether the relevant Pennsylvania laws were similar to those of Nebraska. Instead, the Lowery court simply reasoned that because "a state prison system may define the property in which an incarcerated inmate may gain an interest," interest exists where a state prohibits prisoners from possessing certain items. ${ }^{\text {s1 }}$

Both Sell and Lowery have erred in their analyses by blurring the distinctions between "new property," which was at issue in Roth, and "old property," which is at issue in prison contraband cases.

42. 548 F.2d at 757 ; see supra note 29.

43. The only circuit to cite Sell as authority is the Fourth, in Hanvey v. Blackenship, 631 F.2d 296 (4th Cir. 1980) (upholding permanent confiscation of $\$ 750$ pursuant to specific statutory authority). Hanvey, however, omitted the first step in Sell's reasoning-looking to state law to find a property interest-and instead implicitly assumed that one existed, 631 F.2d at 296.

44. See, e.g., Pepperling v. Crist, 678 F.2d 787, 789 (9th Cir. 1982) (implicit); Sullivan v. Ford, 609 F.2d 197, 198 (5th Cir.) (implicit), cert. denied, 446 U.S. 969 (1980); Wolfish v. Levi, 573 F.2d 118, 131-32 \& n.29 (2d Cir. 1978) (implicit), rev'd on other grounds sub nom. Bell v. Wolfish, 441 U.S. 520 (1979); Lowery v. Cuyler, 521 F. Supp. 430, 434 (E.D. Pa. 1981) (explicit).

45. While it may seem inconsistent to fault Sell for not addressing these arguments but then to reject the arguments as invalid, see infra pp. 912-13, this is necessary because the arguments at first glance appear valid, and only by refuting them will the Sell holding come to exert persuasive authority in other jurisdictions. The few cases citing Sell do so only to address the question of what is required to confiscate contraband once a property interest has been found. See, e.g., Hanvey v. Blankenship, 474 F. Supp. 1349, 1350 (W.D. Va. 1979), aff'd, 631 F.2d 296 (4th Gir. 1980); Brager v. Fenton, No. 79-632 (M.D. Pa. Oct. 29, 1979).

46. 521 F. Supp. 430 (E.D. Pa. 1981).

47. Id. at 432 n.8. The sum at issue was $\$ 1045$. Id. at 430 .

48. Id. at 431 .

49. It is unlikely that the court was even aware of how Sell found a property interest, since the Eighth Circuit's opinion omitted this information. See supra note 29.

50. 521 F. Supp. at 432 (emphasis added).

51. Because the Lowery court saw no property interest at issue, it did not reach the remaining due process questions of whether statutory authority or procedural protections are required for a forfeiture. Lowery rejected Sell on the belief that Bell v. Wolfish, 441 U.S. 520, 547 (1979), which requires that "wide-ranging deference" be shown in the area of prison discipline, had superseded Sell. Lowery, 521 F. Supp. at 434. It is doubtful, however, that the Court in Bell meant to extend this deference so far as to allow a confiscation of contraband in the absence of any due process protection, as Lowery asserts. See infra note 60 . This is particularly true in light of Bell's leaving intact, by failing to address, the Second Circuit's holding below that procedural protections must accompany any seizure of contraband. See 573 F.2d at 131-32 \& n.29; see also Steinberg v. Taylor, 500 F. Supp. 477, 479 (D. Conn. 1980) (following Second Circuit's mandate for procedural protections and noting that Supreme Court's reversal in Bell based on other grounds). 
Roth, relied upon in both Sell and Lowery, dealt with "new property." ${ }^{32}$ New property is property that originally stems from the state and that the state issues to certain individuals or groups. ${ }^{53}$ If a plaintiff can show that the state recognizes the class of persons of which the plaintiff is a member to be entitled to the new property at issue, the resulting property interest may not be denied without due process. ${ }^{54}$ In Roth, for example, the plaintiff, a non-tenured university professor, could show no source of an interest beyond a unilateral expectation in what was in effect a future employment contract. ${ }^{58} \mathrm{He}$ was not entitled to due process before being denied the contract. At no time did he have any right or interest in that future contract, or property; thus, nothing was being taken away from him..$^{s 6}$

In the case of internal prison contraband, however, the situation is quite different. The prisoner's possession of these items was legitimate before he brought them into prison. The prisoner therefore had a constitutionally protected interest in the items recognized by state common law, ${ }^{\mathbf{5 7}}$ and a constitutional right to due process before the prison officials took that property interest from him through confiscation. ${ }^{58}$

Both Lowery and Sell ask whether the state has recognized an interest in prison contraband as prison contraband. In confusing prison contraband with new property, the Sell and Lowery courts erred in where they looked for the origin of the property interest. With an item of new property, the interest always stems directly from the state, and thus where the state has not recognized an interest in the class of persons claiming to be entitled to it, no interest exists. The property interest in internal prison contraband, however, does not come directly from the state but derives from the state's common law recognition of the interest that the possessor

52. See generally Reich, The New Property, 73 YaLe L.J. 733 (1964) (coining phrase).

53. Examples include welfare benefits, services, contracts, franchises, and licenses. Id. at 733 . Old property, in contrast, would include traditional forms of wealth, of which the government is not the source but which are recognized by state common law.

54. See Roth, 408 U.S. at 576-78 (university professor entitled to no due process protections before "loss" of state employment contract because unable to show entitlement to contract); $c f$. Wolff v. McDonnell, 418 U.S. 539, 555-56 (1974) (prisoner entitled to due process before loss of statecreated good-time credits in which he had been given a liberty interest).

55. Roth had been hired for a fixed term of one academic year to teach at a state university. When the university, without explanation and without offering any opportunity to challenge its decision, did not renew his contract at the end of the year, Roth sued, claiming, inter alia, loss of property interest without due process. Roth, 408 U.S. at 566-69.

56. Whether the plaintiff in Roth in fact had more than a unilateral expectation (such as some sort of implied agreement or guarantee) may be disputed, but that is a question of fact. What is important for purposes of this Note is Roth's conclusion that where someone has never gained an interest, no due process questions are raised when he is "deprived" of it, since nothing is being taken away from him.

57. See supra p. 906.

58. See supra note 11. 
had prior to bringing internal prison contraband into prison. ${ }^{59}$ The issue is not whether an interest is gained in prison contraband as such, but whether the interest held prior to the item's entrance into prison is retained.

Lowery also fails to recognize that a prisoner does not lose all of his constitutional rights because of his conviction and incarceration, but only those expressly, or by necessary implication, taken away from him by law. ${ }^{80}$ Although a prisoner may therefore lose his possessory rights in internal prison contraband, he does not lose his ownership rights, ${ }^{61}$ unless they are expressly taken from him by statute, because ownership rights are not inconsistent with the needs and objectives of the prison. It is these rights to which due process protections must attach in prison contraband cases, and thus it is necessary to consider what due process requires before such rights may be taken.

59. The internal prison contraband may have come indirectly from the state, as with money that originally came from a welfare check. But when there is an intermediate step-legal possession outside of prison-a property interest vests in the possessor. See supra note 24. It is this interest to which due process protections attach.

This protection attaches even where inmate $A$ is found in possession of property that he did not bring into prison himself but instead received from inmate $B$, who did bring it in. Where $B$ retains the interest, $A$ may gain that interest-by trading for it or being given it-even under illegal circumstances without the threat of forfeiture to the state, so long as no express statute authorizes forfeiture. An analogous situation exists outside of prison where money is transferred in violation of gambling statutes. Money won in these circumstances and held in the gambler's exclusive possession is not subject to forfeiture without clear statutory authority, because the possessor is deemed to hold a property interest in such property. See State v. Verrilli, 132 Conn. 46, 47-48, 42 A.2d 338, 339 (1945); Chappell v. Stapleton, 58 Ga. App. 138, 139, 198 S.E. 109, 110 (1938).

60. See supra note 10. Lowery's confusion is evident from the opinion's own words:

$[\mathrm{T}]$ he question is whether a state prison system may define the property in which an incarcerated inmate may gain an interest after his incarceration. If it can, and if an inmate is not permitted to acquire certain items, he can have no property interest in such items, and they would therefore not be protectible [sic] within the meaning of the Fourteenth Amendment. The "forfeiture" question would be irrelevant, for there would be no protectible [sic] property interest in the "forfeited" items.

Lowery, 521 F. Supp. at 432. Lowery thus looks not to whether an inmate has lost his ownership right in the property involved, but whether, once in prison, he gains it.

61. Property interests, of course, are made up of many interests, and these interests need not all be held by the same person. For example, while an infant whose estate is being held in trust might have an ownership interest in that estate, he does not have a possessory interest in it. In the same fashion, a prisoner might have an ownership but not a possessory interest in internal prison contraband. An analogy can be found in Hillman v. Stults, 263 Cal. App. 2d 848, 70 Cal. Rptr. 295 (1968), where a prisoner was allowed to exercise his ownership rights to transfer and convey his real and personal property, including jewelry, outside the prison. The Hillman court stated that "[w]hile the Adult Authority has control over the person of the inmate, his outside property does not come within its supervision or control," because "the Penal Code provides that no conviction results in a forfeiture of property except when expressly imposed by law." Id. at 873, 70 Cal. Rptr. at 309; see also In re Harrell, 2 Cal. 3d 675, 702-03, 470 P.2d 640, 658-59, 87 Cal. Rptr. 504, 522-23 (1970) (prisoner's right to inherit property and to own written material produced during imprisonment may not be interfered with by prison officials), cert. denied sub nom. Harrell v. California, 401 U.S. 914 (1971); In re Fein, 51 Misc. 2d 1012, 1014, 274 N.Y.S.2d 547, 550-51, (N.Y. Civ. Ct. 1966) (life prisoner not divested of his ownership rights, but entitled to inherit property and to transfer by will). 


\section{Due Process Requirements for the Confiscation of Prison Contraband}

Once it has been determined that a property interest exists in prison contraband, prison officials may deny a prisoner that interest only if they employ due process. Due process for permanent confiscation of prison contraband requires both clear statutory authority and adequate procedural protections.

\section{A. Statutory Authority Is Required}

When an item in which one has a property interest is permanently confiscated, that confiscation constitutes a forfeiture. The government pays no compensation in forfeiture cases. ${ }^{62}$

Forfeitures are not favored in the law, and will not be upheld except pursuant to clear statutory authority ${ }^{63}$ mere legislative acquiescence in the actions of prison officials is inadequate to justify forfeitures. ${ }^{64}$ Thus,

62. In contrast, in "takings" cases the government must provide just compensation. U.S. CoNST. amend. V. The property taken has never been used in violation of the law but is merely something that the government must, by reason of public necessity, appropriate to itself (e.g., land for a highway). See J. Dukeminier \& J. KrIeR, Property 1128-29 (1981). A forfeiture, however, is "a divestiture of property in consequence of a default or an offense." Ballantine's LAw Dictionary 489 (3d ed. 1969). The illegal use of the property results in forfeiture to the state; thus, no compensation is required. See King v. United States, 292 F. Supp. 767, 772 (D. Colo. 1968) ("Forfeiture is quite different from condemnation in that the latter requires the payment of just compensation."); see also Sell, 548 F.2d at 758 (quoting King for same point).

63. In United States v. Lane Motor Co., 199 F.2d 495 (10th Cir. 1952), aff'd, 344 U.S. 630 (1953), the defendant regularly used his automobile to transport himself between his home and his illegal still. Id. at 496. The relevant statute called for the forfeiture of "property intended for use in violating . . . the internal-revenue laws, or regulations prescribed under such . . . laws." Id. at 497. In invalidating the forfeiture, the court stated: "[F]orfeitures are not favored and should be enforced only when within both the letter and spirit of the law." Id.; see also United States v. One 1977 Cadillac, 644 F.2d 500, 501 (5th Cir. 1981) ("As a general rule, forfeiture is not favored, and statutes providing for forfeiture are strictly construed."); City of Anchorage v. Thomas, 624 P.2d 271, 273 (Alaska 1981) ("We are naturally reluctant to impute to the legislature an intent to impose a forfeiture unless expressly authorized or absolutely necessary to further a legitimate public interest."). The specificity of legislative intent required by Thomas parallels that required to deprive a prisoner of constitutional rights that he would enjoy outside of prison. See supra note 10.

Courts are reluctant to give effect to forfeiture statutes even where equity or "natural justice" would support forfeiture. See King v. United States, 292 F. Supp. 767, 771 (D. Colo. 1968) (although government could take actual possession of rifle used to assassinate President Kennedy and although "natural law" or "natural justice" "demanded" forfeiture, compensation necessary in absence of statute authorizing forfeiture).

64. Legislative acquiescence should not be construed as an intent to delegate the requisite authority to confiscate prison contraband permanently because it is doubtful that many legislatures have ever considered the problem. As the Supreme Court stated:

In order to decide whether [legislative] acquiescence should give . . . the same support as an express statutory . . . command, it is appropriate to review the extent to which the [agency's] policy has been given consideration by Congress . . . and the nature of the authority specifically delegated....

Hampton v. Mow Sun Wong, 426 U.S. 88, 105 (1976) (emphasis added); see also Sandalow, Judicial Protection of Minorities, 75 Mich. L. Rev. 1162, 1188 (1977) (stressing need to assure that governmental institutions, subordinate to Congress, which make decisions about fundamental rights do so 


\section{Prison Contraband}

courts must ensure that prison confiscations do not occur where legislatures have do not clearly intended to authorize them. ${ }^{65}$

Some states have exercised their power to enact express statutes with regard to permanent confiscation of prison contraband. ${ }^{66}$ Unfortunately, however, courts in prison contraband cases often hold general delegations of authority to prison officials to be sufficient grounds for such confiscation. ${ }^{67}$ Although general statutes could be said necessarily to authorize

only when Congress has deliberately so authorized); $c f$. C. Black, Structure AND Relationship IN ConstrTUtIONAL LAW 88-89 (1969) (noting with disapproval that in "overwhelming majority of [police investigations] the only extrajudicial determination of the propriety or constitutionality of the conduct concerned is . . not Congress, not the legislature, not the governor, not even the city council, but Chief Doe [the chief of police]").

Actions by the Eighth Circuit and legislatures within that jurisdiction illustrate that legislatures probably have given little or no consideration to the issue of whether contraband should be subject to permanent confiscation. Until 1977, the Eighth Circuit invariably dismissed claims regarding confiscation of prisoners' property on the ground of deference to wardens' disciplinary authority or because property claims were believed to state no civil rights action by themselves. See, e.g., Rhodes v. Sigler, 448 F.2d 1237 (8th Cir. 1971) (citing both grounds as reason for dismissal); Howard v. Swenson, 426 F.2d 277 (8th Cir.) (same), cert. denied, 400 U.S. 948 (1970). It might be argued that the legislatures' acquiescence in these judicial interpretations implied an intent to authorize forfeitures. Since 1977, however, when the Eighth Circuit in Sell overruled its earlier approach and prohibited confiscation without express statutory authority, the legislatures have continued to acquiesce. For example, the Nebraska statutes involved in Sell have not been changed. See NEB. REv. STAT. \$\$ 83-173(6), (11) \& 83-185(1), (2) (1981) (annotation noting Sell's interpretation of statute); see also Iowa CoDE ANN. § 218.4 (West 1969) (directors of particular correctional institutions shall recommend rules "they may deem necessary for the discharge of their duties"); MINN. STAT. ANN. §§ 241.01-.32 (West 1972) (control and supervision of department of corrections relegated to corrections commissioner); N.D. CENT. CoDE § 12-47-23 (1976) (same); S.D. Codified Laws ANN. § 24-2-6 (1979) (warden may use "[a]ll necessary means . . . to maintain order in the penitentiary . . .."). But see Mo. ANN. STAT. $§ 217.365$ (1983) (enacted in 1982, expressly authorizing permanent confiscation of money held as prison contraband). Such inaction suggests that the issue of permanent confiscation in the prison context has received little legislative consideration; thus, legislative silence should not be taken as an intention to delegate such authority.

65. Cf. City of Anchorage v. Thomas, 624 P.2d 271, 273 (Alaska 1981) (proceeds from tax foreclosure sale of real property may not be forfeited absent clear statutory authority). An analogy may help illustrate the issue at hand. Suppose that NASA or the Pentagon, without the authorization of Congress but pursuant to its own administrative regulations, permanently confiscated any cameras brought into its facilities. Although such agencies may, as a necessary implication of the functions of their facilities, have sufficient authority to prohibit cameras or to confiscate the film in the cameras, there is no such inherent need to confiscate permanently the cameras themselves. Such a forfeiture would require explicit legislative action. See supra note 63. Because prisoners do not lose all of their rights upon conviction and incarceration, but only those which would be inconsistent with incarceration, see supra note 10 , they retain the same ownership rights in prison contraband as the hypothetical visitors to NASA or the Pentagon retain in their cameras.

66. See, e.g., VA. CoDE §53-23.1 (1978) ("Any item of personal property, tangible or intangible, which an inmate in any penal institution is prohibited from possessing . . . shall, when found in the possession of an inmate, be confiscated and sold or destroyed as the Board, or its designated agent, may direct."), discussed in Hanvey v. Blankenship, 474 F. Supp. 1349, 1350 (W. D. Va. 1979), aff'd, 631 F.2d 296 (4th Cir. 1980); FiA. STAT. ANN. § 402.18(3) (West 1975) ("Any contraband found upon, or in the possession of, any patient or inmate in any [state] institution under the jurisdiction of any [state] division shall be confiscated and liquidated and the proceeds thereof shall be deposited in the welfare trust fund of the division."), discussed in Sullivan v. Ford, 609 F.2d 197 (5th Cir.), cert. denied, 446 U.S. 969 (1980). The Sullivan court noted this provision, 609 F.2d at 197, but based its holding upon judicial deference to prison officials, id. at 198.

67. In federal prisons, prison officials are authorized "to provide for the protection, instruction, and discipline" of all inmates. 18 U.S.C. $\$ 4042(3)(1976)$. This general statute was cited as sufficient 
temporary confiscations in order to provide for the protection, instruction, and discipline of prisoners, ${ }^{68}$ no such implication exists to authorize permanent confiscations.

First, an ownership interest in contraband is not inconsistent with the warden's need to maintain discipline and security among convicted prisoners. ${ }^{69}$ Once the items are out of the prisoner's actual possession, the danger they present no longer exists. ${ }^{70}$ The threat of permanent confiscation is also not a necessary deterrent, because alternative forms of discipline are available. ${ }^{71}$ Second, permanent confiscation of certain types of property (e.g., large sums of money) might hinder prisoners' efforts to reestablish themselves upon their release and thus work against the goal of rehabilitation. ${ }^{72}$ Finally, permanent confiscation raises potential problems of equity among prisoners: Loss of a given amount of property will have an unequal impact on prisoners depending on their personal financial status.

Nor is permanent confiscation of prison contraband authorized merely by reason of a prisoner's conviction. This type of discipline, a taking of his property, exceeds the limitations placed on a prisoner's constitutional rights by virtue of his conviction ${ }^{73}$ and thus is not within prison officials' disciplinary discretion. Whereas prison officials may circumscribe certain

authority to confiscate permanently $\$ 25$ in Brager v. Fenton, No. 79-632, slip op. at 3 (M.D. Pa. Oct. 29, 1979). The Pennsylvania law used in Lowery to uphold the permanent confiscation of $\$ 1045$ gave corrections officials authority "to promulgate by-laws, rules and regulations for the management of [state prisons]." PA. STAT. ANN. tit. 71, § 306(d) (Purdon 1962), quoted in Lowery, 521 F. Supp. at 432.

68. Even here, however, the warden's discretion is limited in that the prohibition must be a reasonable limitation in light of security or other legitimate concerns of the prison. Bell v. Wolfish, 441 U.S. 520,554 (1979).

69. Consistent with the notion of distinguishing between possessory rights and ownership rights, see supra note 61 , Sell stated:

It is familiar law that possession of property is of two kinds, actual and constructive. Granting

that the prison authorities had the right to deprive the plaintiffs of the immediate actual possession and enjoyment of the funds in question, the exercise of that right did not necessarily destroy the right of the plaintiffs to have the funds deposited to their accounts on the prison

books or held for ultimate return to them and thus remain in their constructive possession. 548 F.2d at 757.

70. For an example of a court that has simply missed this point, see Sullivan v. Ford, 609 F.2d 197, 198 (5th Cir.) (upholding permanent confiscations in part on basis that actual possession poses danger to prison security), cert. denied, 446 U.S. 969 (1980).

71. For example, officials might instead deprive a prisoner of privileges or good-time credits, place him in segregation, or increase his work requirements. These alternatives may be less effective deterrents, and prison officials are in a good position to discern this. But because forfeitures are so disfavored in the law, this discretion should not be given to prison administrators unless it is clear that the legislature has so intended. See supra note 64. For examples of courts upholding permanent confiscation as a necessary deterrent, apparently due to a failure to perceive the availability of alternative forms of discipline, see Lowery v. Cuyler, 521 F. Supp. 430, 433 (E.D. Pa. 1981); Cardwell v. Hogan, 23 Ariz. App. 475, 534 P.2d 283, 284-85 (1975).

72. Where the only statutes that can be found are those which authorize temporary confiscation, officials should be required to send the property to persons outside the prison whom the prisoner has designated. The inmate has lost only the right actually to possess the property, not to transfer it as he wishes. See cases cited supra note 61 .

73. See supra note 10. 
liberty interests (provided they do not take more liberty than that which was lost as a result of the conviction), ${ }^{74}$ they have no discretionary power over the contraband at issue in these cases, because a prisoner's ownership interest in the contraband is neither lost, nor subject to loss, as result of the initial conviction.

\section{B. Procedural Protections Must Be Afforded by Prison Officials}

Even where statutory authority exists for permanent confiscation of a property interest in contraband, prisoners may not be deprived of it unless prison officials provide at least some procedural protections. ${ }^{78}$ Until such protections are provided, the prisoner retains an interest in the items, ${ }^{76}$ and unless the protections are provided within a reasonable time period, the forfeiture will be declared invalid. ${ }^{77}$

Courts have yet to analyze carefully the procedural protections required. ${ }^{78}$ The Lowery court stated that since no property interest existed in the contraband, confiscation required no procedural protection under the due process clause of the Fourteenth Amendment. ${ }^{79}$ The Sell court

74. See Vitek v. Jones, 445 U.S. 480 (1980) (involuntary transfer to mental hospital implicated protected liberty interest); Greenholtz v. Inmates of Nebraska Penal \& Correctional Complex, 442 U.S. 1,7 (1979) (conviction extinguishes one's liberty right to be conditionally released before expiration of valid sentence); Meachum v. Fano, 427 U.S. 215, 224 (1976) (holding that involuntary transfer of Massachusetts state prisoner from medium-security to maximum-security prison did-not affect any liberty interest, as his conviction had "constitutionally deprived [him] of his liberty to the extent that the State may confine him and subject him to the rules of its prison system so long as the conditions of confinement do not otherwise violate the Constitution").

75. Cf. Wolff v. McDonnell, 418 U.S. 539, 557-58 (1974) (prisoners' property interest protected by due process clause).

76. The property interest is said to vest in the government the moment that the property is used in violation of a statute that calls for its forfeiture. See supra note 22 . Pending the completion of an adequate procedure, however, the government's title is only conditional. The earlier "vesting" appears to be a judicial fiction used to protect the government against persons to whom a sale or gift is made after the violation of the statute but before the completion of procedural due process. As stated by the Supreme Court in United States v. Stowell, 133 U.S. 1 (1890):

[T] ]he forfeiture takes effect immediately upon the commission of the act; the right to the prop-

erty then vests in the United States, although the title is not perfected until judicial condemna-

tion; . . . . [T] The condemnation, when obtained, relates back to . . . the time [of the offense],

and avoids all intermediate sales and alienations, even to purchasers in good faith.

Id. at 16-17 (emphasis added); see also United States v. Eight Rhodesian Stone Statues, 449 F. Supp. 193, 195 n.1 (C.D. Cal. 1978) (conditional right to property vests in government upon forfeiture but government's title not perfected until decree of judicial condemnation obtained).

77. United States v. One Motor Yacht Named Mercury, 527 F.2d 1112, 1114 (1st Cir. 1975) (12 $1 / 2$ month delay in commencing forfeiture proceedings violated due process clause and required return of the property); United States v. One Douglas A-26B Aircraft, 436 F.Supp. 1292, 1298-99 (S.D. Ga. 1977) (8 $\frac{1 / 2}{2}$ month delay violated due process).

78. With the exception of Sell, the courts that have addressed this question have done so only to require a determination as to whether or not the items in question were contraband; they have not recognized a property interest in contraband, see supra p. 907.

79. Lowery, 521 F. Supp. at 432 . This was only dictum, however, as a hearing had been provided, id. at $430 \mathrm{n} .1$, during which the plaintiff was presumably given an opportunity to justify his possession of the items. 
vaguely required that prisoners be given "adequate procedural safeguards" and an "opportunity to justify the possession." Cases not directly discussing the property interest in internal prison contraband provide some insight into other courts' visions of the minimum requirements of due process. ${ }^{81}$

It is both difficult and impractical to establish in the abstract what process is due in the various cases that may arise in the prison setting. ${ }^{82}$ The Supreme Court, however, has stated the general factors to be considered in deciding what process is due in property cases: (i) the private interest that will be affected by the official action; (ii) the risk of an erroneous deprivation of such interest through the procedures used, and the probable value, if any, of additional or substitute procedural safeguards; and (iii) the government's interest, including the function involved as well as the fiscal and administrative burdens that the additional requirement would entail. ${ }^{83}$

The importance of a prisoner's interest will depend in large part on the value of the items. It will also vary according to whether the confiscation is temporary or permanent: Though due process protections attach even to temporary confiscations, ${ }^{84}$ more procedural protections would be required for permanent confiscations since the prisoner loses not only his possessory interest, but his ownership interest as well. ${ }^{85}$ The difference in accuracy that additional protections will make depends in large part on the nature of the property. With some items, such as weapons or marijuana, deter-

80. Sell, 548 F.2d at 759 .

81. The Ninth Circuit held the following safeguards adequate for the seizure of contraband in which no property interest was recognized: The seizure was entered into a formal log; notice was provided to the prisoner within twenty-four hours of confiscation; and there was a right of appeal to a committee whose members did not make the initial decision to confiscate. Sherman v. MacDougall, 656 F.2d 527, 528 (9th Cir. 1981). In United States ex rel. Wolfish v. Levi, 439 F. Supp. 114, 151 (S.D.N.Y. 1977), aff'd sub nom. Wolfish v. Levi, 573 F.2d 118 (2d Cir. 1978), rev'd on other grounds sub nom. Bell v. Wolfish, 441 U.S. 520 (1979), the court said that prisoners must be given a receipt and accorded "certain [other] minimal procedures," including notice of right to respond in a reasonable and timely manner, the opportunity to meet and answer controverted evidence, and a decision with reasons, however brief.

82. The primary aim of this Note is not to discuss the advantages and disadvantages of various kinds of procedural protections, nor even to suggest which ones at a minimum must be provided. The primary aim is to show that a property interest does exist in prison contraband, and that this interest may not be abridged without clear statutory authority and some procedural protections. The present section is included to point out what considerations are pertinent when courts review the protections which are provided, and that the full panoply of protections need not be offered in every case.

83. Mathews v. Eldridge, 424 U.S. 319, 335 (1976).

84. Fuentes v. Shevin, 407 U.S. $67,84-86$ (1972) ("[1]t is now well settled that a temporary, nonfinal deprivation of property is nonetheless a 'deprivation' in the terms of the Fourteenth Amendment . . . [T] The length and consequent severity of a deprivation may, however, be another factor to weigh in determining the appropriate form of hearing .....").

85. The Note does not dispute the principle that permanent confiscations are constitutional if no property interest is implicated as, for example, where the items are contraband per se or where there is adequate statutory authority for permanent confiscation, see statutes cited supra note 66. 
mining what they are and that their possession is illegal is quite simple. With other items, however, such as literature that the warden deems pornographic or otherwise dangerous to prison discipline and security, the determination may be more difficult. Protections required will also depend on whether the prisoner, in his initial complaint, admits that the property was contraband. ${ }^{86}$ The government's interest will vary according to the nature of the property, the urgency of the need to remove it from the prisoner's possession, the difficulties presented in storing it, and the procedural protections that would be required to determine whether or not it is in fact contraband.

\section{CONCLUSION}

Rather than continuing to dismiss prison contraband cases, courts should address the basic due process questions presented. When courts do address these questions, they should avoid the error of confusing internal with external prison contraband and of looking to whether the state has recognized a property interest in prison contraband as such. Instead, courts should note that the property interest held outside the prison is retained even after the property is brought into the prison. Finally, courts must recognize the requirements of due process and demand that a prisoner's property not be permanently confiscated absent clear statutory authority and unless adequate procedural protections have been provided.

- Michael O. Hill

86. In United States v. Storer Broadcasting Co., 351 U.S. 192 (1956), the Supreme Court significantly limited the extent of an applicant's hearing right by allowing the FCC to deny a hearing to broadcast license applicants who were plainly and automatically disqualified by its regulations. Where the regulations were reasonable and the plaintiff's application failed on its face to meet the regulations' requirements, the Court permitted the FCC to preclude plaintiff from having a full hearing. The Court's holding should not be taken to mean that the plaintiff was not entitled to at least some procedural protections (e.g., a review of the application to discern whether or not it did in fact plainly fall outside of the regulations' ambit). As stated in Wolff v. McDonnell, 418 U.S. 539, 557-58 (1974), the plaintiff was entitled to "some kind of hearing." A "hearing," however is a "verbal coat of too many colors," Friendly, "Some Kind of Hearing," 123 U. PA. L. REv. 1267, 1270 (1975) (quoting United States v. Tucker Truck Lines, Inc., 344 U.S. 33, 39 (1952) (Frankfurter, J., dissenting)), and in some cases even procedures as sketchy as those given in Storer might meet the test, id. at 1272-73. 